\title{
It's Okay Even If You Are a Spy: Issues in Researcher Positioning Within a Precarious Workplace
}

\begin{tabular}{|r|l|}
\hline Journal: & Journal of Organizational Ethnography \\
\hline Manuscript ID & JOE-12-2018-0047.R2 \\
\hline Manuscript Type: & Research Paper \\
\hline Keywords: & $\begin{array}{l}\text { Access, Seafarers, Rapport, Workplace Ethnography, Positioning, } \\
\text { Precarious Employment }\end{array}$ \\
\hline \multicolumn{2}{|l}{} \\
\hline
\end{tabular}

\section{SCHOLARONE ${ }^{m}$ \\ Manuscripts}



Workplace

\section{Abstract \\ Purpose:}

The purpose of this paper is to examine some of the complexities associated with the trust-building process between participants and researcher in the context of a precarious work environment. Specifically, the paper seeks to discuss issues arising from the power dynamics, mistrust and tensions between different stakeholders in the research (i.e. employers, employees and the researcher), and the implications of such relationships for establishing rapport and trust with research participants.

\section{Design:}

This paper uses the case of the shipping industry and is based upon findings from two research projects. One project examined similarities and differences between the merchant vessel and Goffman's theoretical conceptualisation of 'total institutions' (Goffman, 1961); the other focused on the increasing flexibility of labour in the global labour market, using the case of shipping. Both projects incorporated ethnographic research methods which included three voyages on board merchant vessels, as well as interviews and informal conversations with over 100 participants.

\section{Findings :}

The researcher encountered several obstacles throughout the projects, many of which related to the access to the restricted workplace setting of a cargo ship. However, this paper is based on her positioning in the field after permission to access the ship had been granted by the shipping company. It was often challenging to overcome participants' suspicions of the researcher as being sent by the company to spy on them. The researcher generally managed to overcome such suspicions in the course of her fieldwork by building relationships with participants over time. Nevertheless, these relationships were influenced by the complex power dynamics amongst the different stakeholders in the field. The challenges encountered in the field sites suggest that researchers should be open and fluid in the ways they present themselves in the field. The findings potentially offer useful insights for novice researchers whose research focuses on 
workplace settings characterised by precariousness of employment and for those conducting shipboard research.

\section{Originality/value:}

The main contribution of this paper lies within its ability to shed light on the often-delicate relationships between different stakeholders in a research project, and the influence of these relationships on a researcher's continuous access to the field. The experiences described in this paper are based on the global shipping industry, but they are also relevant to other closed, isolated and/or restricted research settings. Specifically, experiences described in this paper are similar to those of researchers studying 'closed' research environments that are not accessible to the general public; this is particularly the case where a hierarchical work structure controls to some extent the roles played by different stakeholders within the precarious work environment, potentially influencing the way someone from outside the workplace approaches it. These include, for example, government owned establishments such as prisons, mental hospitals as well as privately owned closed business organisations.

\section{Introduction}

This paper focuses on issues relating to access and rapport within closed and restricted settings based on my experiences in two research projects (2010-2018), which involved me negotiating access to and sailing with three cargo vessels. The paper aims to discuss issues relating to researchers' positioning in the field with consideration of the interactions and power dynamics between different stakeholders. In this case, I claim that when the unique relationships between researcher, employers and employees in a closed, hierarchical and precarious [1] workplace that is part of a commercial business organisation are formed, researchers need to carefully navigate these power relationships, as these ultimately shape their data collection in the field through different stages.

In both studies, the focus was on seafarers working on merchant vessels. The first project was undertaken for a period of three years, examining seafarers' experiences on board merchant vessels through Goffman's theoretical conceptualisation of 'total institutions' (Goffman, 1961). The second project was undertaken for a period of five years, using the shipping industry as a case for examining precarious employment practices in the global labour market, specifically on the increasing flexibility of labour in the global labour market, using the case of shipping. Ethnographic fieldwork was conducted on board three cargo vessels, in what can be termed 'overt research' (Bryman, 2012; Hammersley and Atkinson, 
1995), where both gatekeepers and participants were conversant with the research being conducted and informed consent forms were signed. Conversations and interviews were conducted in Hebrew, English and Russian. In all cases, the ships sailed to several countries along the Mediterranean Sea coast for periods ranging between 12-16 days. To maintain seafarers' anonymity, all names used in this paper are pseudonyms. Information about research participants can be seen in Figures $1-3$.

$$
\begin{aligned}
& \star \star * \text { Figure 1: Age groups of participants } * * * \\
& \star \star \star \text { Figure 2: Roles held by participants***} \\
& \star \star * \text { Figure 3: Origin Countries of Participants } * *
\end{aligned}
$$

\section{Ethnographies of Organisations}

Collecting reliable and valid data requires people's trust, thereby enabling researchers to gain insight into their lives and experiences. The importance of gaining trust with participants is evident in social research, particularly in the context of ethnographic research (Alcadipani and Hodgson, 2009; Bryman, 2012; Goffman, 1961; Green et al., 2017; Hammersley and Atkinson, 1995) where ethnographers spend a considerable amount of time with participants. When it comes to conducting research on any group in an organisation, Goffman (1961, p. 7) notes how a good way to learn about members of organisations is 'to submit oneself in the company of the members to the daily round of petty contingencies to which they are subject.' In this respect, gaining participants' trust often requires researchers to participate 'overtly or covertly, in people's daily lives for an extended period of time' (Hammersley and Atkinson, 1995, p. 1). In order to do this, however, researchers need, first and foremost, to gain access to the organisational setting within which they wish to conduct their study.

The issue of access to research data has been a well-covered topic in ethnographic studies (Bryman, 2012; Hammersley and Atkinson, 1995; Lumsden, 2009; Warden, 2013). Brannick and Coghlan (2007) define access in two 'stages', whereas primary access generally means obtaining permission to get into the organisation to undertake research, while secondary access refers to building relationships to gain access to people and information within the organisation. Secondary access is not just about opening doors', but about the 'researcher gaining the acceptance, credibility, and trust of organisational members' (Cunliffe and Alcadipani, 2016, p. 545). Challenges to access are described as the 'most acute' during the initial attempts to enter a research field (Hammersley and Atkinson, 1995, p. 54). The problems of access are not fully resolved once the researcher has gained entry to the setting, however. 
Hammersley and Atkinson (1995, p. 79) emphasise how 'negotiation of access is therefore likely to be a recurrent preoccupation for the ethnographer'. Ethnographic research in business organisations can present unique access issues since these are often considered 'closed' research settings (Bryman, 2012, p. 433) where access is generally limited to outsiders. In this respect, gaining the trust of members in a business organisation characterised by precarious working conditions can present additional challenges for researchers, as described throughout the paper. Some of the challenges encountered prior to and during data collection are presented, with special emphasis on the distinctiveness of gaining access to participants in the shipping industry. This paper contributes to the field of organisational ethnography by presenting an example of the often-delicate relationships between different stakeholders in an organisation, and the influence of these relationships on a researcher's continuous access to the field.

\section{The global shipping industry}

The global shipping industry, perhaps more than any other, has been greatly influenced by growing cost-saving strategies over the years. The drive to reduce labour costs and additional processes relating to globalisation have created a strongly precarious work environment for seafarers with minimal regulations of work conditions (Alderton et al., 2004; Baum-Talmor, 2018; Gekara et al., 2013). Seafarers' employment generally involves short-term voyage-based contracts, and subsequent employment may not necessarily be with the same company and/or on board the same ship. At the end of any contract, they generally become unemployed (Leong, 2012), and they lack many social benefits such as pension schemes, medical insurance or life insurance (Dutt, 2015; Sampson, 2013). Often seafarers are forced to wait long periods of time between contracts (Baum-Talmor, 2018; Sampson, 2013); even when they have a contract, they may experience a constant fear of job loss, as the renewal of their contract is not guaranteed. The nature of employment in the global shipping industry reflects the growing use of precarious working arrangements among contemporary business organisations (Beck, 2000; Kalleberg, 2009; Vosko, 2010).

Ships have been compared to and have been found to bear similarity to 'total institutions' (TIS) in some respects, even though they clearly differ from TIs in others (BaumTalmor, 2018; Davies, 1989; Gerstenberger, 1996; Goffman, 1961). On the one hand, the ship is a place of residence and work, where seafarers as 'like-situated individuals' (Goffman, 1961, p. 11) are physically isolated from the shore and other people for extended periods of time (Baum-Talmor, 2018; Davies, 1989). On the other hand, the ship cannot be 
considered a TI in its entirety, and as some critiques of the concept claim that TIs are never entirely cut off from the outside world (Gill et al., 2018; Moran, 2016). In this respect, the cargo ship can be considered a 'moving world' or as Michel Foucault calls it, a 'heterotopia par excellence' (Faubion, 1998, p. 185) which is strongly linked to the surrounding world. Taking into account the precariousness of employment in shipping as noted above, it is possible to look on the research field from a similar perspective taken by Geppert and Pastuh (2017) who studied the retail industry, and applied the concept of TIs to the analysis of employment practices 'which have been labelled as 'precarious' or 'abusive' in the context of a 'normal' business organisation' (Geppert and Pastuh, 2017, p. 256).

Within the context of the research upon which this paper is based, there are complex power relations between the company personnel ashore and the crews on board the ship worth considering. This research found that seafarers' perceptions of the company's employment practices were overwhelmingly negative, and they reported financial difficulties between contracts (e.g. falling into debt). Most seafarers interviewed portrayed a general sense of insecurity in their employment, and some expressed a fear of their employer, seen to have all the power to terminate their contracts. In this backdrop, the shipping industry presents interesting barriers to researchers trying to access it, where seafarers' perceptions of the researchers could be set within the unbalanced power dynamics between them and their employer. Employers, too, might have reservations when it comes to providing access to researchers, for instance due to the exposure of malpractices or due to the fact that ships are considered closed and restricted work environments. For example, it is likely that employers who do not comply with the industry's global regulations in relation to seafarers' employment (Bloor and Sampson, 2009) are unlikely to be open about such malpractices with researchers, even when anonymity is guaranteed.

\section{Negotiating initial access: Gatekeepers and stakeholders in shipping}

When it comes to accessing the global shipping industry, Sampson and Turgo (2018, p. 3) note how this industry is a 'geographically dispersed, elite, and exclusive field for research which renders access and engagement challenging'. Bearing similarity to other ethnographic settings (e.g. Gouldner, 1954; Lumsden, 2009; Warden, 2013), there are several 'layers' of gatekeepers in shipping that researchers need to go through. The first gatekeeper would be the shipping company that needs to approve the researcher's access to the ship. 
In both research projects, gaining access to employers in the shipping industry proved to be challenging. Attempts to contact potential gatekeepers were made early on in both projects, in order to secure a research voyage. In my correspondence I presented myself as a student who is interested in seafarers' lives and welfare, as well as their motivations to work on board. A detailed account was kept of the people who could potentially assist with data collection. Nevertheless, despite dozens of letters, emails and phone calls, in most cases these attempts did not result in an interview or in access to a ship.

Primary access (Brannick and Coghlan, 2007) was eventually achieved through a gatekeeper in a global shipping company owning and operating a fleet of approximately 150 vessels worldwide. The first successful contact with the company was established in the early $2010 \mathrm{~s}$ and was what can only be described as a 'lucky break'. The HR manager contacted me over the phone as a response to a letter sent to the company, and said he was interested in the project. Consequently, a meeting was scheduled, at the end of which the gatekeeper along with another colleague were very supportive of the project and made the arrangements to facilitate a voyage on board. There was no explicit request for information on behalf of the company representatives, which raised concerns that a request for tangible or intangible output might arise at a later stage, as noted for example in Sampson and Turgo (2018).

In order to maintain a positive relationship with the company that could potentially lead to additional research voyages, I felt compelled to produce a report of some kind, albeit not having been asked to. Having prepared a presentation with seafarers' photos from my first voyage on board for the seafarers' enjoyment, it seemed sensible at the time to show the presentation to the company representative as a token of gratitude. Without intending to do so, however, and despite the fact that the presentation was received positively, it also prompted several comments regarding seafarers' work practices on board, for example, in relation to health and safety regulations. For instance, the manager commented on seafarers not wearing protective equipment even though they were photographed during their break time. The HR manager also noted how, judging by my photos, the ship resembled a cruise ship rather than a working cargo ship. The company's reaction to the presentation has provided a valuable insight on the research field and the power relations between the company and the seafarers working on board. Subsequently, the presentation played a crucial role in facilitating further access to the research field, which was arranged through the same company approximately six months later. To demonstrate, during a conversation I had with the captain on board at the beginning of my second voyage, he mentioned how the deputy HR 
manager had spoken favourably of my previous voyage and my presentation.

Having established some contacts in the shipping industry during the first project, I commenced the second project in 2013 believing that access to my third voyage be easier, which transpired to be a somewhat naïve assumption. Starting a new project in a different country, I was not sure my previous connections were still viable, thus I attempted to negotiate access to new shipping companies found through an online search. However, as these efforts were largely futile, I resorted back to pre-existing contacts where I managed to secure a research voyage. At this time, however, there had been a change in management and the new contact person made an explicit request for information about my experience on board at the end of the voyage. This presented an ethical dilemma in the sense that I needed to negotiate my position and find the balance between maintaining access to the ship while not compromising seafarers' trust, anonymity and confidentiality. Even though I clearly explained the ethical limitations to what I could and could not share with him, I felt that this request placed me in a difficult position. Bell and Bryman (2007) note how organisational researchers often find themselves in a weak bargaining position compared to other disciplines when trying to gain access to their field, as business organisations usually operate on a cost-benefit model, expecting something in return for their cooperation. Accessing closed research settings such as the global shipping industry often means that to secure access, 'researchers in relatively weak positions have to make use of non-material resources in order to win the 'favour' of more powerful gatekeepers' (Sampson and Turgo, 2018, p. 2). Eventually, to appease the contact person at the company and to maintain an option for future access, I stated that all results would be published and available in an online report at the end of the project. Nevertheless, the access granted by the company underpinned my presence on the ship and inexorably influenced my position on board, as shown later in the paper.

While the company representative would have been the obvious gatekeeper in the field, as Cunliffe and Alcadipani (2016, p. 546) note: 'obtaining permission from such a person does not necessarily mean that all employees ... will welcome the researcher'. Although access to the ship was facilitated through the company representative ashore, contact with them ceased for the duration of the fieldwork, so regardless of any previous arrangements made with the company representative ashore, to facilitate a successful study I needed to be accepted and trusted by seafarers on board. 


\section{Accessing the ship and seafarers on board}

The ship is considered a relatively unusual location for conducting fieldwork, as I discovered during my first research project. Other researchers who have conducted shipboard research note how the ship is an isolated work environment that often presents increased researcher risk and restricted options for communication with the outside world (Baum-Talmor, 2012; Bloor et al., 2010; Sampson and Thomas, 2003).

Additionally, ships often sail for extended periods and access to the shore may be limited or impossible at times (Ellis et al., 2012).

In other settings, once access is secured, participants are generally in a position to walk away or not engage with the researcher. However, people on board a cargo vessel, myself included, are physically isolated from the shore (Baum-Talmor, 2014; Sampson, 2013); once the boat has left the port, people are not in a position to easily disengage from the research. Seafarers are compelled to live and work alongside the researcher; they see me every mealtime, and every day I spend most of my time in their working spaces. These circumstances played an important role in the relationships between different stakeholders in the research, including the relationships with the shipping company employees ashore, who are physically isolated from those at sea. In this respect, the researcher's presence on board can be seen as an intrusion of the managerial gaze in seafarers' 'protected' and normally isolated working space. This could further influence the perception of the researcher as a 'representative' of the company that can often be perceived as an 'enemy' in the minds of some seafarers.

In addition to the power dynamics between the company and seafarers, there are several stakeholders within the hierarchical structure of the ship worth mentioning. The highest authority on a typical cargo ship is the captain, who generally acts on behalf of the ship's owner and is responsible for the day-to-day matters on board the ship (Sampson, 2013). The captain can be seen as the main gatekeeper researchers need to 'win over' once on board, having the power to grant access and smooth their entry into the field. In some instances, captains are potentially in a position to derail research projects by preventing investigators from conducting their studies (e.g. Sampson and Thomas, 2003). Under the captain, crews generally adhere to a very strict hierarchical structure (Baum-Talmor, 2018; Sampson, 2013), divided into officers and non-officers (ratings). Table 1 presents a short overview of roles generally held on board, according to seniority.

$* * *$ Table 1: Typical hierarchy of jobs on board cargo $\operatorname{ships} \star \star \star$ 
Shipboard hierarchy normally exists through a clear chain of command and through a physical separation between officers and ratings, including separate accommodation, eating areas as well as 'social' spaces e.g. TV rooms for officers and ratings [4]. It is important to note that a researcher's status on board is more likely to be associated with officers rather than with ratings, as the researcher is generally seen as the 'company guest,' hence under the captain's responsibility. In both projects I have managed to secure the captain's approval for conducting the research, thus the next 'layer' of stakeholders on board was the crew under the captain's command, which form the majority of participants in the project.

\section{Acceptance and rapport}

The significance of proximity to the participants to facilitate cooperation is mentioned by Adler and Adler (2001) who note that regularly approaching respondents enables researchers to discuss complex issues and cultivate a deeper intimacy with them. Spending time with people in their workplace has been noted as one way of overcoming potential resistance and founding a relationship with them prior to the interview (Adler and Adler, 2001). At the beginning of my fieldwork on every ship I downplayed my researcher role and tried to connect with people in an informal way. I found that the first few days in the field were often beneficial for establishing rapport with the crew, during which seafarers gradually started to show interest in me as a guest on board. I consistently tried to spend time in seafarers' work areas and other communal spaces on board, which often prompted some seafarers to take notice of me and to start conversations. On one occasion, while spending time in the communal TV room, one seafarer started asking questions about my studies and others soon followed. By exchanging information and answering seafarers' questions, I was able to 'enter' a deeper level of the field which later on helped my data collection.

I tried to convince crewmembers to take part in the project in various ways, and there were several interactions in the field that later had a substantial impact on data collection. one example was a routine safety drill which took place several days into the voyage after which I seized the opportunity to present myself and my research properly. At the end of the drill, all seafarers were assembled in the office to discuss it after which the senior officer introduced me as a student, explaining that I was not there on behalf of the company. As a result, some seafarers became friendlier towards me, which facilitated access to more people.

While some events were fortuitous in facilitating access to seafarers, in other instances I actively created events in 
order to establish more meaningful relationships with seafarers outside of their workplace. Once when the ship berthed in Barcelona, I invited several seafarers for a night out off the ship [2]. This outing, however, took its toll on some of the seafarers who showed up to work the next day tired and unfocused, at least according to the First Engineer Dagmer [3]. While having lunch with Dagmer, he told me how seafarers who went out the night before were completely exhausted, resulting in him sending one of them to rest in his cabin. This outing seemed to create a real sense of comradery among those involved, and consequently established a bond with these seafarers who subsequently appeared to feel more comfortable with me. However, the unintended consequence of this event was that it impinged on the crew's functionality and had the potential to compromise their safety.

I sometimes felt that I managed to immerse myself in some aspects of the crew's life on board, while not in others. While speaking to Dagmer (the First Engineer), another seafarer named Tycho (serving as Chief Engineer) entered the room and appeared quite irritated with everyone present. I was not spared in this instance and was scolded along with everybody else. Even though Tycho had agreed to a recorded interview earlier, he often interfered with my research by interfering or glowering near my conversations with other people; this was despite the fact that our interactions were taking place during free time (as opposed to time demanded for work activities). The following illustrates this:

I was sitting with Eddison the cadet and the
chief engineer Tycho seemed angry with me sitting
there. ... I asked Eddison if I was distracting him
from work and he said that he already finished his
duties for the day. [Fieldnotes, second voyage]

Despite the negative experience with Tycho and his reproachful attitude towards me, these events turned out to be positive as they facilitated later conversations with other seafarers under his command. It seemed that I was, as it were, 'in the same boat' as them when I was criticised by their superior officer at the same time as them; thus a friendly connection was made because we now shared a common 'enemy'. In a sense, the hierarchical relationship between Tycho and his inferiors partially shaped the interaction between me and the participants, and rather than being associated with the 'power' of the senior officers, I was now grouped with the 'weaker' group, which deepened my rapport and acceptance with the ratings. On several other occasions throughout the fieldwork, some ratings noted how I was 'different from other guests on board' since I tried to spend time with all seafarers equally, rather than mainly with the higher-ranking crew. These experiences suggest that I managed, at least to 
some extent, to build rapport and trust with some seafarers on board which was the purpose of the voyage, and which enabled me to collect rich and interesting data. However, this was not always the case.

\section{Suspicion and resistance}

In both projects, after almost two weeks spent on board, I managed to establish trust with most of the seafarers who agreed to recorded interviews. However, some seafarers did not agree to take part in the research, recorded or not. In this respect, suspicions of my intentions on board had several features, including seafarers' perception of me as a 'spy' and the power dynamics within the context of a precarious work environment.

As some people have no or little knowledge of social research, researchers can often be perceived as a threat in the field, whereas 'field researchers are frequently suspected, initially at least, of being spies' (Hammersley and Atkinson, 1995, p. 80). The closed research field of the cargo ship (Alderton et al., 2004; Sampson and Turgo, 2018) placed me in an ambiguous position from the seafarers' point of view, since I boarded the ship with no apparent nautical skills nor family connections to any seafarer [5]. To assert my independence from their employer (Green et al., 2017), one of the common questions I was asked by seafarers related to my stay on board, with particular interest shown in discovering whether someone was paying for my passage. While no direct payment was received from the company for conducting the research, my access to the vessel meant all food and board were provided for the duration of the voyage, which, in turn, meant that the company indirectly paid for my voyage by agreeing to me being on the ship. While I did pay some fees to the company in two out of the three voyages to cover basic costs and local taxes, generally I was not charged for joining the vessel, which might have been perceived as suspicious by seafarers (who sometimes asked questions about who funds my stay on board) and inevitably positioned me as having a hidden connection to the company.

In a handful of cases, some seafarers were hostile towards me from the outset and despite several attempts to speak to them throughout the fieldwork, their reluctance to take part in the research persisted. For example, overt resistance to the idea of a researcher on board was evident during the second research project, where one seafarer questioned me from the moment I set foot on board. After I was helped to board the ship through the gangway, I was met by the AB Alton, who signed me in onto the ship's logbook and introduced me to the third mate Euron, who bluntly said in Hebrew: 'so you're here to investigate us, huh?' I gained the impression that he did 
not favour the idea of having a researcher on board. When the ship reached deep sea, he seemed slightly more at ease and after sharing some information about himself, openly said that he believed I was sent by the company to spy on seafarers on board. Even though Euron 'softened up' towards the end of the voyage and had numerous informal conversations with me, he never overcame his suspicions to the extent that he agreed to be recorded. In this respect, the issue of the 'managerial gaze' interfering with the seafarers' work environment played a role in Euron's perceptions, as he could not disassociate me from his employer, constantly feeling like he was being 'watched'.

In another case, one seafarer on board the first ship refused to talk to me at a very early stage of my research, and despite spending over two weeks in the vicinity of that seafarer, he declined to partake in the project. The following notes document my frustration with this:

I believe I met my first reluctant respondent on board, his name is Tormund, he seems to oppose my research fundamentally. When [I tried to initiate a conversation with him] he said something along the lines of 'no one is telling you the truth when you ask them questions, even though I'm not sure what exactly you're asking them...' I told him that he didn't have to answer any of my questions, and he seems to have chosen not to participate. [Notes from first voyage]

I came to terms with Tormund's explicit opposition to the research, but his reluctance to participate took a turn for the worse when I realised that he was actively sabotaging my access to other informants of his nationality (i.e. Polish). I noticed how most of the Polish seafarers were following Tormund's approach, avoiding contact with me and shying away from my attempts to schedule interviews. In this context, what might have played a role in their suspicion was their origin from a country with a 'history of mass surveillance' (Beresniova, 2017).

\section{Fluid identity in the field}

This aspect of gaining rapport and trust could also be linked to my personal background. Abu-Lughod (1991, p. 137) refers to 'halfies' as those whose 'national or cultural identity is mixed by virtue of migration, overseas education, or parentage.' I was born in Latvia while it was under Russia's communist regime, and then spent most of my life in Israel, which could classify me as a 'halfie,' having a mixed cultural identity. Based on several informal conversations in the field, I discovered how my USSR origin has likely played a 
role in my positioning in the field. With my name and details appearing on the crew list (freely available to all

seafarers), my place of birth was a known fact on board. Some seafarers came from countries that were previously occupied by the USSR or were affected in one way or another by the Communist Regime, for example Poland, Romania and Ukraine. In both projects, there were seafarers from these countries who explicitly refused to take part in the research and treated me suspiciously from the outset.

On another occasion during the first voyage, I was walking around the vessel with my camera taking pictures of the different spaces of the ship. At one point, I was trying to take an artistic picture of my surroundings, which was observed by the bosun. He was Romanian and asked me if I was a spy taking pictures of the crew. It was not clear whether his question was a serious one. Later on, when I saw him on the bridge, I showed him the picture I had taken but he did not seem to be too impressed by this. In consequent conversations with other crew members, it was implied that my Ex-Soviet origin had played a role in his choice of words. In this case, I had no control over the way I was perceived in the field. Being a 'halfie' enabled me to have a deeper understanding of issues associated with Soviet 'surveillance' and the way seafarers could perceive my position as a 'spy', but also thwarted my access to some of them [6].

Being aware of such possible perceptions, in turn, enabled me to negotiate my role in the field and establish relationships with seafarers based on my other 'ascribed' characteristics (Hammersley and Atkinson, 1995) such as my gender, my age group and my ethnic identification [7]. With reference to the latter, my ability to speak Russian enabled some seafarers to express themselves in their mother tongue which led to rich and meaningful data. In terms of my age, I tried to use 'marginally similar experiences' (Tewksbury and Gagné, 1997, p. 133) to those of seafarers in order to enhance the research process. For example, being in my $30 \mathrm{~s}$ while conducting the study resembled the age group of some seafarers with whom I shared references to music, films and video games; this served as another means of building trust and rapport. These experiences could also be related to the fluctuating identities in the field and the influential role identity plays in a researcher's positioning in the field, as also noted by Gosovic (2018) and Merriam et al. (2001). Another identity I 'flaunted' (Mazzei and O'Brien, 2009) was my gender. Some seafarers often associate women with a 'caring' role (Acejo and Abila, 2016; Sampson and Thomas, 2003), making them more likely to share their feelings and experiences with a female researcher. Similarly, in some cases in the field, seafarers shared their problems with me, telling me how they missed their families and how they did not get along with 
their superiors, which enabled a greater understanding of their experiences at work.

There is a 'grey' area between full cooperation and obvious resistance to the researcher as I discovered during fieldwork, which can also be linked with the power dynamics of different stakeholders in shipping. For example, I was baffled by my relationship with some who, although largely cooperative, still assumed I had been sent by the company. On one occasion at the end of a recorded conversation with a trainee cook, I asked him a routine question of whether the interview had made him feel uncomfortable or intimidated. He replied that it had not, but he also added: 'it's okay even if you are a spy,' stating further he would feel comfortable talking to me because he did not have anything to hide. I was concerned by his comment, as it highlighted the fact that even after spending a considerable amount of time with seafarers it was difficult to convince them I was not sent by the company . Undoubtedly, boarding a ship for data collection has facilitated rich and invaluable data, but following his comment, I questioned whether my efforts in arranging a voyage on board for interviewing seafarers was the most effective way to gather the information I needed, rather than, for example, accessing them while their ship was berthed ashore. Subsequently, even though I did manage to collect the data that answered my research questions, my relationships with the seafarers were shaped to some extent by the power dynamics between them and the company, where seafarers held the underlying assumption that $I$ was sent to the ship to spy on them.

In other cases, seafarers were willing to participate but did not agree to be recorded. It would have been ideal to have an official recording of all my interactions with seafarers. Recorded conversations can produce a comprehensive account of conversations conducted when compared to the pen-and-notebook approach which inevitably means the loss of much detailed information (Hammersley and Atkinson, 1995, p. 186). However, this was not always possible. On one such occasion, for example, I interviewed a captain about his experiences at sea and he explicitly asked me not to record the interview, which meant I needed to capture what was said on paper. In this instance, the captain appeared to trust me to the extent of sharing information about his life and experiences at sea but did not agree to have a physical record made of the conversation apart from notes. This was due to suspicion on his behalf that the recording might end up in the wrong hands.

During a recorded interview with a captain on board a different ship, he expressed his concerns about the destiny of the recording, explaining that his reservations related to his fear it could potentially reach the company [8]. On another occasion, I had a plethora of informal conversations with one 
bosun, but when I tried to initiate a recording of our interaction that was particularly useful for the research, he refused. After trying to schedule a convenient time for him to record a conversation, he politely admitted he preferred not to be recorded. The participant had voiced many personal opinions which were often critical of his employer and of management on board, and he preferred not to have a formal recording of these exchanges for fear of job loss.

While my ascribed positioning as a spy shaped some relationships with the seafarers on board, there are other reasons that can be identified regarding seafarers' reluctance to participate in the research. In their paper about reluctant respondents, Adler and Adler (2001, p. 528) note how sometimes research respondents within a workplace setting can find themselves in a vulnerable position due to fears about losing their jobs. A 'fear' of the employer is particularly noticeable within the context of the global shipping industry and the precariousness of seafarers' employment, as noted earlier.

On one occasion, after listening to a recording of an interview with a seafarer, I noticed how his attitude developed defensive undertones when I asked him a relatively standard question about the length of his contract, when he replied:

I don't know... and besides, it can change. If I want to do another round [on board], they give me the option to do that. So I cannot say anything [bad] about the company, I'm sure they are working as they should be, I'm not saying they are not. [Jojen, Deck Officer]

Jojen's cautious manner illustrated his misgivings that if anything negative was said to me about the company, it might be shared with his employer, consequently compromising his employment. Other conversations I had with Jojen supported the view that he was convinced I was sent by the company to spy on seafarers, and he was cautious in what he told me.

Another dimension of seafarers' misapprehension of my positioning in the field sometimes involved requests they wanted me to 'pass on' to the company. For example, during an interview with an electricity cadet, he spoke very positively about the company and openly promoted himself as a candidate for a training program the company was funding at the time:

I already have one-year experience, that type of main engine, and that type of ships. So actually, I think that I will be a great candidate, you know, for that [course]. [Matthos, Electrician Cadet ] 
As Tewksbury and Gagné (1997, pp. 140-141) observe: 'no matter how careful researchers may be about selfpresentations, we can never be in total control of the impressions we make on others'. Matthos' assumptions about my connection to the company brought about his attempt to promote himself to the company; this contrasts with Euron, who saw the negative watchful eye of his employer through my presence on board. Matthos actually wanted to be noticed by his employer, and tried to use my presence on board to do that.

Additionally, seafarers' reluctance to participate in the research could be related to their general unfamiliarity with academic research which might have raised suspicions as many of them had not previously encountered a researcher on board. It is also possible that the intense and all-encompassing schedule of the ship led to seafarers' fatigue (Wadsworth et al., 2008), meaning some were too tired and preferred spending their 'off-work' time on their own in their cabins. The intensive nature of fieldwork on board the ship also took its toll on me and sometimes I was too tired to carry on with mundane conversations, feeling the pressures of shipboard isolation and fatigue myself. This helped me to understand more deeply the experience of seafarers' life and work on board, even though this shared experience occasionally thwarted attempts to develop relationships in the field.

\section{Conclusion}

By negotiating access through the shipping company, on three occasions I managed to gain initial access to what can be considered the closed and precarious work environment of the cargo ship (Bryman, 2012; Sampson and Turgo, 2018). However, this immersive ethnographic approach did not always best serve my interests or increase rapport with the participants; it was often mitigated by the underlying power dynamics between the company and the seafarers working on board. In the cases where the seafarers were convinced that I was sent by the company, my relationships were negatively affected. It is important to acknowledge that researchers need to be able to accept that they cannot 'win them all' and even though we may strive to speak to as many people as possible, some respondents will never be persuaded to take part in the research, as this paper demonstrates.

The issues covered in this paper are analysed through an ethnographic framework, placing the research within the comprehensively covered topics of access and rapport. The paper examines issues arising from the power dynamics between different stakeholders in what can be termed a 'precarious' workplace, using the case of the shipping industry. In this respect, the shipping industry has been affected by different processes relating to globalisation, which have created a 
strongly precarious work environment for seafarers with minimal regulations of work conditions (Alderton et al., 2004; Baum-Talmor, 2018; Gekara et al., 2013). Seafarers' employment generally involves short-term voyage-based contracts, at the end of which they normally become unemployed (Leong, 2012) for an unlimited period of time. Seafarers experience a constant fear of job loss, lacking many social benefits such as pension schemes, medical insurance, life insurance (Dutt, 2015; Sampson, 2013). Research shows how seafarers' perceptions of their employment are overwhelmingly negative (Baum-Talmor, 2018 ).

My work exposes some of the implications of these dynamics for the establishment of rapport and trust with research participants. The main contribution of this paper lies within its ability to shed light on the often-delicate relationships between different stakeholders in a research project in a hierarchical setting, and its influence on researchers' continuous access to participants. Another aspect to emphasise in this respect relates to the ethical dilemmas often faced by researchers in closed research organisations, whereas researchers are required to cautiously navigate polarised organisational settings. In this project I had to carefully manage my stance with the company who provided access to the ship vis-à-vis my relationship with the research participants, ensuring I was not compromising seafarers' trust, anonymity and confidentiality while maintaining a positive relationship with the company. At the end of the study, I sent out the research reports to the company and had made it publicly available, with anonymised results whereas seafarers' responses could not be traced back to particular individuals.

The experiences described in this paper are based on the global shipping industry, however, they could be relevant to other closed or restricted research settings. For instance, events described in this paper could be similar to those of researchers studying other 'closed' research environments that are not accessible to the general public, especially where a hierarchical work structure involves different stakeholders within a precarious work environment. This could potentially influence the way someone from outside the workplace approaches the field, and the ways they are perceived. For example, research in mental hospitals, prisons or other closed business organisations could present similar issues. In these types of environments, the hierarchical structure of the organisation, determining the power relationships between the different stakeholders, can play a significant part in a researcher's positioning and ability to build rapport. 


\section{References}

Abu-Lughod, L. (1991) 'Writing Against Culture', in Fox, R.G. (ed.) Recapturing Anthropology: Working in the Present (Seminar Papers). Washington: University of Washington Press, pp. 137-162.

Acejo, I. L. and Abila, S. S. (2016) 'Rubbing Out Gender: Women and Merchant Ships', Journal of Organizational Ethnography, 5(2), pp. 123-138.

Adler, P. A. and Adler, P. (2001) 'The Reluctant Respondent', in Gubrium, J.F. \& Holstein, J.A. (eds.) Handbook of interview research: Context and method. Thousand Oaks: Sage Publications, Incorporated.

Alcadipani, R. and Hodgson, D. (2009) 'By any means necessary? Ethnographic access, ethics and the critical researcher', Tamara: Journal for Critical Organization Inquiry, 7(4), pp. 127-146.

Alderton, T., Bloor, M., Kahveci, E., Lane, T., Sampson, H., Thomas, M., Wincehster, N., Wu, B. and Zhao, M. (2004) The global seafarer: Living and working conditions in a globalized industry. Geneva: International Labour Office.

Baum-Talmor, P. (2012) From Sea to Shore: An Ethnographic Account of Seafaring Experience (in Hebrew). M.A. Dissertation [Unpublished], Department of Sociology and Anthropology, University of Haifa, Israel.

Baum-Talmor, P. (2014) 'From sea to shore: Ethnographic account of seafarers' experience on-board merchant ships', Sage Cases in Methodology, pp. 1-17, Available: Sage Research Methods. DOI: http://dx.doi.org/10.4135/978144627305013508492 (Accessed 1 January 2015).

Baum-Talmor, P. (2018) Careers and Labour Market Flexibility in Global Industries: The case of seafarers. PhD Thesis, Cardiff University, Cardiff [Online] Available at: http://orca.cf.ac.uk/109438/ (Accessed: 11 May 2018).

Beck, U. (2000) The brave new world of work. Translated by: Camiller, P. London/New York: Cambridge University Press.

Bell, E. and Bryman, A. (2007) 'The ethics of management research: an exploratory content analysis', British Journal of Management, $18(1)$, pp. 63-77.

Beresniova, C. (2017) 'She's Our Spy: Power and Positionality in Studying Lithuanian Teacher Communities', in Silova, I. \& Sobe, N.W. (eds.) Reimagining Utopias: Theory and Method for Educational Research in Post-Socialist Contexts. Rotterdam, Netherlands: Sense Publishers, pp. 15-31. 
Bloor, M., Fincham, B. and Sampson, H. (2010) 'Unprepared for the worst: risks of harm for qualitative researchers', Methodological Innovations Online, 5(1), pp. 45-55.

Bloor, M. and Sampson, H. (2009) 'Regulatory enforcement of labour standards in an outsourcing globalized industry the case of the shipping industry', Work, Employment \& Society, 23(4), pp. 711-726.

Brannick, T. and Coghlan, D. (2007) 'In defense of being "native": The case for insider academic research", Organizational Research Methods, $10(1)$, pp. 59-74.

Bryman, A. (2012) Social Research Methods. 4th edn. Oxford: Oxford University Press.

Cunliffe, A. L. and Alcadipani, R. (2016) 'The politics of access in fieldwork: Immersion, backstage dramas, and deception', Organizational Research Methods, 19(4), pp. 535-561.

Davies, C. (1989) 'Goffman's concept of the total institution: Criticisms and revisions', Human Studies, 12(1-2), pp. 77-95.

Dutt, M. (2015) Indian Seafarers' Experiences of IllTreatment Onboard Ships. PhD Thesis, Cardiff University, Cardiff, UK [Online] Available at: http://orcamwe.cf.ac.uk/71472/2/Manasi $\% 20$ Dutt $\% 20 \mathrm{Final} \div 20$ Thesis $\% 200 R \mathrm{C}$ A.pdf (Accessed: 25 July 2017).

Ellis, N., Sampson, H., Acejo, I., Tang, L., Turgo, N. and Zhao, Z. (2012) Seafarer accommodation on contemporary cargo ships, Cardiff, UK: Seafarers International Research Centre (SIRC). Available at: http://maritimeconnector.com/documents/Seafarer\%20Accommodation.pdf (Accessed: 18 September 2018).

Faubion, J. D. (1998) Michel Foucault: Aesthetics, methods and epistemology (Essential works, volume II)(R. Hurley, Trans.). New York: The New Press.

Gekara, V. O., Acejo, I. and Sampson, H. (2013) 'Re-Imagining Global Union Representation Under Globalisation: A Case of Seafaring Labour \& the Nautilus International CrossBorder Merger', Global Labour Journal, 4(3), pp. 167-185.

Geppert, M. and Pastuh, D. (2017) 'Total institutions revisited: What can Goffman's approach tell us about 'oppressive'control and 'problematic'conditions of work and employment in contemporary business organizations?', Competition and Change, 21(4), pp. 253-273.

Gerstenberger, H. (1996) 'Men Apart: The Concept of "Total Institution" and the Analysis of Seafaring', International Journal of Maritime History, 8(1), pp. 173182 . 
Gill, N., Conlon, D., Moran, D. and Burridge, A. (2018) 'Carceral circuitry: New directions in carceral geography', Progress in Human Geography, 42(2), pp. 183204 .

Goffman, E. (1961) Asylums: Essays on the Social Situation of Mental Patients and other inmates. England: Penguin.

Gosovic, A. K. J. (2018) 'Social identities in the field: how fluctuating fieldworker identities shape our research', Journal of Organizational Ethnography, 7(2), pp. 186-198.

Gouldner, A. W. (1954) Patterns of industrial bureaucracy. New York: The Free Press of Glencoe.

Green, T., Swailes, S. and Handley, J. (2017) 'The significance of unforeseen events in organisational ethnographic inquiry', Journal of Organizational Ethnography, 6(3), pp. 190-203.

Hammersley, M. and Atkinson, P. (1995) Ethnography: Principles in practice. 2nd edn. London: Routledge.

Kalleberg, A. L. (2009) 'Precarious work, insecure workers: Employment relations in transition', American Sociological Review, 74(1), pp. 1-22.

Leong, P. (2012) Understanding the seafarer global labour market in the context of a seafarer 'shortage'. PhD Thesis, Cardiff University, Cardiff [Online] Available at:

https://orca.cf.ac.uk/52229/1/PhD 20thesis\%20Priscilla 20 Leong.pdf (Accessed: 25 July 2017).

Lumsden, K. (2009) 'Don't Ask a Woman to Do Another Woman's Job': Gendered Interactions and the Emotional Ethnographer', Sociology, 43(3), pp. 497-513.

Mazzei, J. and O'Brien, E. E. (2009) 'You got it, so when do you flaunt it? Building rapport, intersectionality, and the strategic deployment of gender in the field', Journal of Contemporary Ethnography, 38(3), pp. 358-383.

Merriam, S. B., Johnson-Bailey, J., Lee, M.-Y., Kee, Y., Ntseane, G. and Muhamad, M. (2001) 'Power and positionality: Negotiating insider/outsider status within and across cultures', International Journal of Lifelong Education, 20(5), pp. 405-416.

Moran, D. (2016) Carceral geography: Spaces and practices of incarceration. London: Taylor and Francis.

Sampson, H. (2013) International seafarers and transnationalism in the twenty-first century. Series Title: New Ethnographies. Manchester: Manchester University Press. 
Sampson, H. and Thomas, M. (2003) 'Lone Researchers at Sea: Gender, Risk and Responsibility', Qualitative Research, $3(2)$, pp. 165-189.

Sampson, H. and Turgo, N. N. (2018) 'Finding the way into a global industry: The usefulness of elite events to social science researchers', Journal of Organizational Ethnography, 7(1), pp. 2-15.

Tewksbury, R. and Gagné, P. (1997) 'Assumed and presumed identities: Problems of self-presentation in field research', Journal Sociological Spectrum, 17(2), pp. 127155 .

Vosko, L. F. (2010) Managing the Margins: Gender, Citizenship, and the International Regulation of Precarious Employment. Oxford: Oxford University Press.

Wadsworth, E. J., Allen, P. H., McNamara, R. L. and Smith, A. P. (2008) 'Fatigue and Health in a Seafaring Population', Occupational Medicine, 58(3), pp. 198-204.

Warden, T. (2013) 'Feet of clay: Confronting emotional challenges in ethnographic experience', Journal of Organizational Ethnography, 2(2), pp. 150-172.

\section{Notes}

[1]. The word 'precarious' is used here mostly to address the lack of job security among seafarers.

[2]. Such spaces are not available on all ships, but they were available on the voyages I undertook.

[3]. In this respect, this outing was not considered to have interfered with data collection for the project, as my research topic was not social interaction on board.

[4]. As noted in the introduction, all names used in this paper are pseudonyms to maintain participants' anonymity.

[5]. This might have looked suspicious since only a maritime related person or someone who is a family member of such person would be permitted to access to a working cargo ship. There are commercial shipping companies that take passengers for a fee, however, travellers on such ships generally have restricted entry to the operational spaces on board. In contrast, I enjoyed unrestricted access to all spaces in all the voyages covered in this paper.

[6]. Despite the relationships I managed to establish with some seafarers on board, I will never presume to say I fully understand how seafarers, particularly those who were affected in one way or another by the Communist Regime, might feel when it comes to Soviet occupation. However, it is important to acknowledge 
that their background likely played a role in the ways they perceived me at the time.

[7]. Examples of how researchers' gender and personal attributes play a crucial role in their acceptance in the field can also be seen in Lumsden (2009); Mazzei and O'Brien (2009); Sampson and Thomas (2003).

[8]. I managed to reassure him that all research materials were kept covertly and confidentially and were only accessible by myself and my supervisors for the purposes of the research. 
Figure 1 - Age Groups of Participants

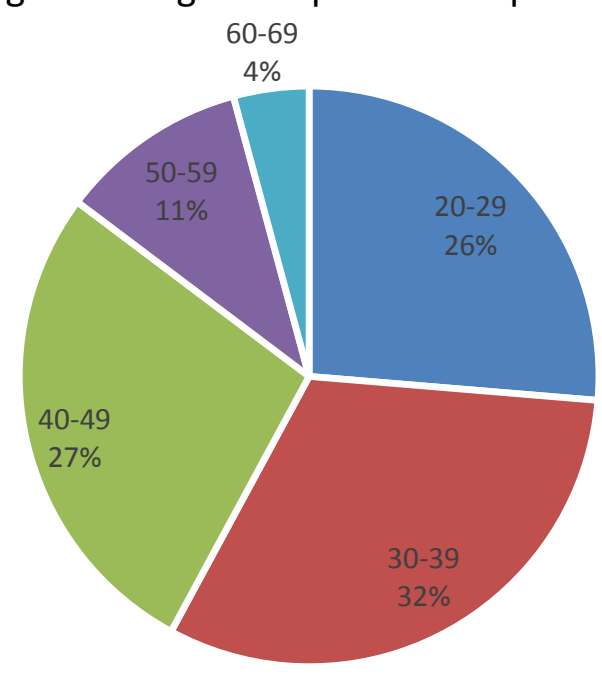

20

21

22

23

24

25

26

27

28

29

30

31

32

33

34

35

36

37

38

39 
Figure 2 - Roles Held by Participants

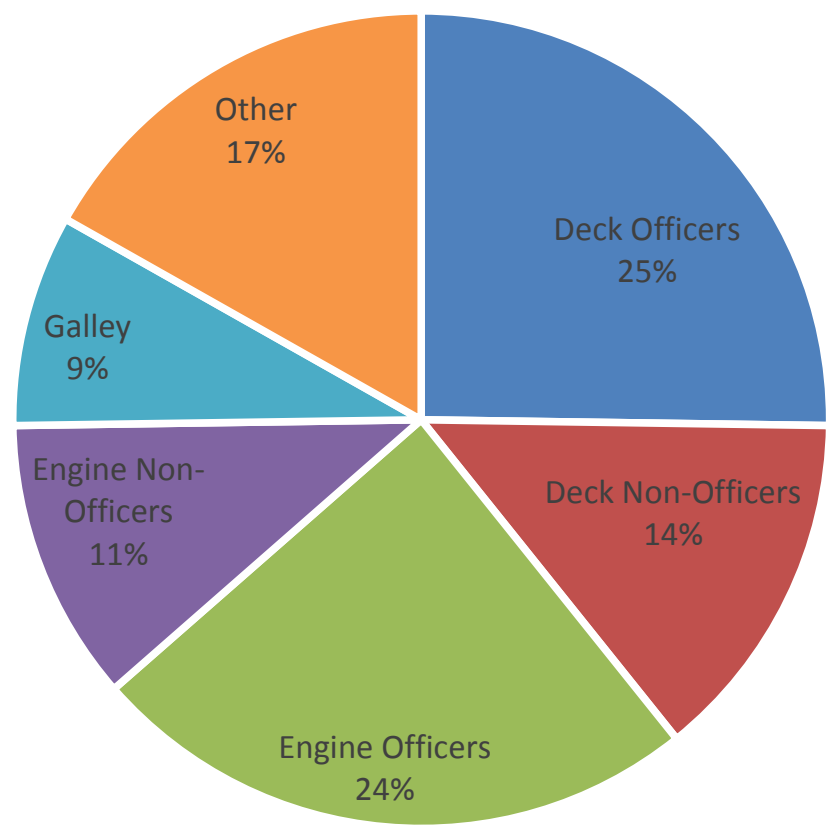

25

26

27

28

29

30

31

32

33

34

35

36

37

38

39

40

41

42

43

44

45

46

47

48

49

50

51

52

53

54

55

56

57

58

59

60 
Figure 3 - Origin Countries of Participants

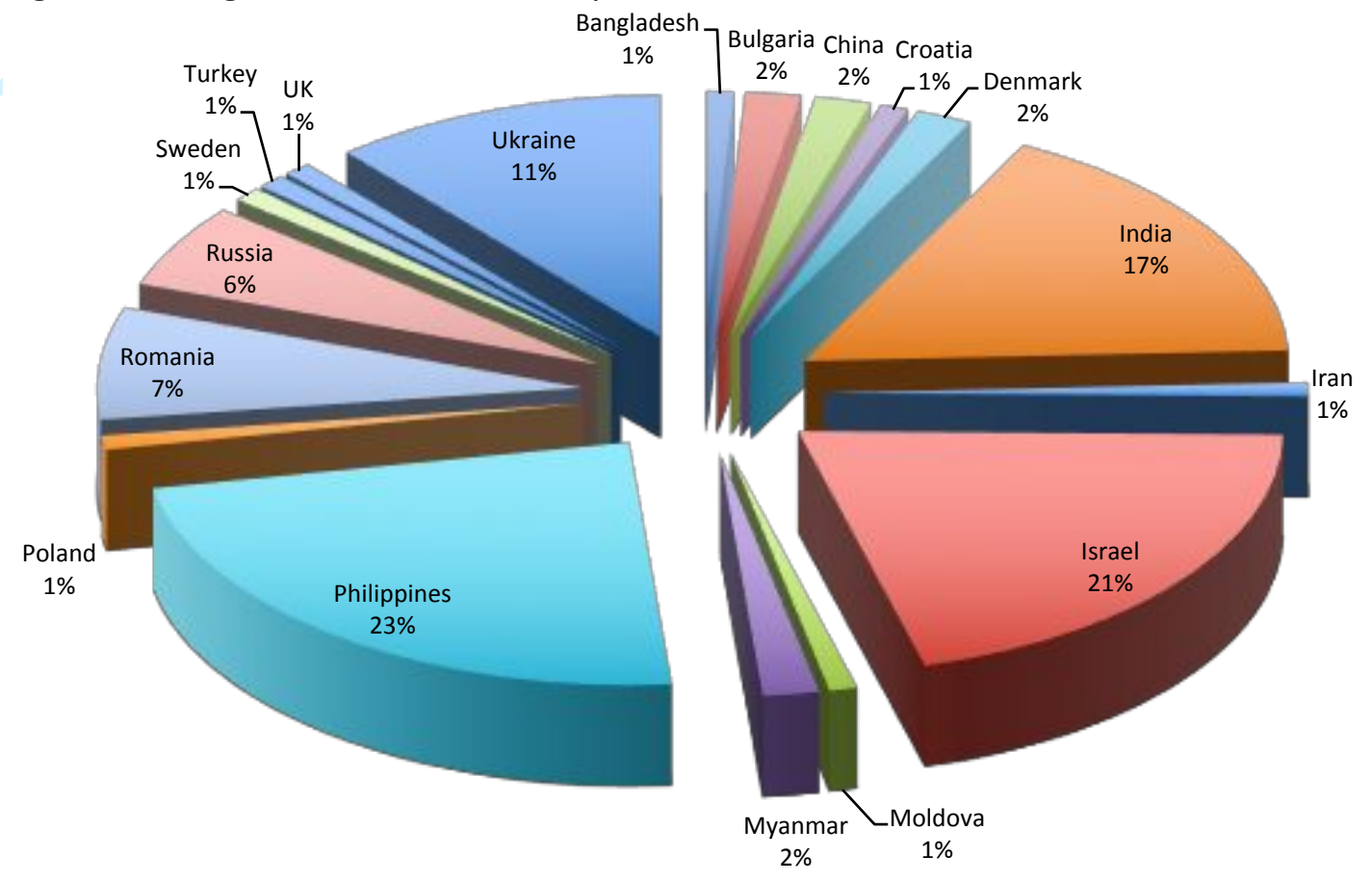


Table 1: Typical hierarchy of jobs on board cargo ships*

\begin{tabular}{|l|l|}
\hline Unit & Personnel \\
\hline Deck Department & Officers \\
& Captain \\
& Chief Mate/Officer \\
& Second Mate/Officer \\
& Third Mate/Officer \\
& Deck Cadet/Officer \\
\cline { 2 - 3 } & Ratings \\
& Boatswain (Bosun) \\
& Able Seaman (AB) \\
& Ordinary seaman (OS) \\
\hline Engine Department & Officers \\
& Chief Engineer \\
& Second Engineer \\
& Third Engineer \\
& Fourth Engineer \\
& Engine Cadet \\
\cline { 2 - 3 } & Ratings \\
& Motorman \\
& Electrician \\
& Oiler \\
\hline Stewards/Galley & Wiper \\
\hline department & Officers \\
& Chief cook \\
& Chief Steward \\
\cline { 2 - 2 } & Ratings \\
& Steward \\
& Mess man \\
& Second cook \\
\hline
\end{tabular}

*Compiled with reference to roles on board cargo ships, Baum-Talmor (2018) and Sampson (2013). 